\title{
100 Years Geologische Vereinigung and Geologische Rundschau
}

\author{
Daniel Bernoulli $\cdot$ Christian Dullo $\cdot$ Gerold Wefer
}

Published online: 26 August 2010

(C) Springer-Verlag 2010

The 2010 is a special year for the Geologische Vereinigung. The inaugural meeting of our Association was held on January 8th, 1910 at the Senckenberg Museum in Frankfurt a.M. (see the report of the first meeting in the Geologische Rundschau, volume 1, issue 1 1910).

Mr. Kayser (Marburg) welcomed the large number of attending geologists and friends of geological science, some of whom had travelled a great distance to the meeting, and briefly outlined the goals of the Association. After cordial words of welcome by Mr. zur Strassen (representing the Senckenberg Natural Science Society) and Mr. E. Naumann (in the name of the Geological Society of Frankfurt), a draft of the by-laws was discussed and approved with only minor changes and additions. The subsequent election of an Executive Committee resulted in acceptance of the list put forward by Mr. Steuer (Darmstadt).

Chairman: E. Kayser (Marburg)

Vice Chairman: Ch. Barrois (Lille)

Vice Chairman: G.A.F. Molengraaff (The Hague)

Vice Chairman: A. Rothpletz (Munich)

Vice Chairman: V. Uhlig (Vienna)

Secretary: Fr. Drevermann (Frankfurt a.M.)

Vice Secretary: R. Richter (Frankfurt a.M.)

\footnotetext{
D. Bernoulli

Basel, Switzerland

e-mail: daniel.bernoulli@unibas.ch

C. Dullo $(\square)$

Kiel, Germany

e-mail: cdullo@ifm-geomar.de

G. Wefer

Bremen, Germany

e-mail: gwefer@marum.de
}

Editor: G. Steinmann (Bonn)

Co-editor: W. Salomon (Heidelberg)

Co-editor: O. Wilckens (Bonn)

Treasurer: H. Schulze-Hein (Frankfurt a.M.)

The warm words of welcome sent by E. Suess and V. Uhlig (Vienna) and by E. Holzapfel (Strassburg) were received with enthusiastic applause, and the recommendation by the chairman to invite Mr. E. Suess to assume honorary chairmanship of the new Association was unanimously approved. (The acclaimed geologist accepted the honour with gracious thanks sent by telegraph on the following day.) A large number of applications for membership were received from near and far, especially from teachers, many with enthusiastic messages of endorsement. The chairman was able to proclaim, with justification, that the goal of the Geologische Vereinigung was obviously a good one, because by the end of the meeting, over 150 applicants had already requested to join. Mr. Steinmann (Bonn) then gave a comprehensive report on his negotiations with various publishers and finally submitted a publishing concept by the Wilhelm Engelmann Company of Leipzig, which was approved by the assembly after a short discussion and a few clarifications. The chairman then closed the business portion of the meeting with a word of appreciation for the active participation in the discussions.

After a break, Mr. Steinmann and Mr. Wilckens (Bonn) as well as Mr. Salomon (Heidelberg) each gave a short talk on a specific chapter from the last volume of Suess' Antlitz der Erde ('The Face of the Earth' - see the account in the first volume of the Geologische Rundschau). In the evening, a friendly gathering at the Kaufmännische Verein (Merchants Club) brought the first meeting of the Geological Association to a close. This was the beginning of the Geologische Vereinigung. 


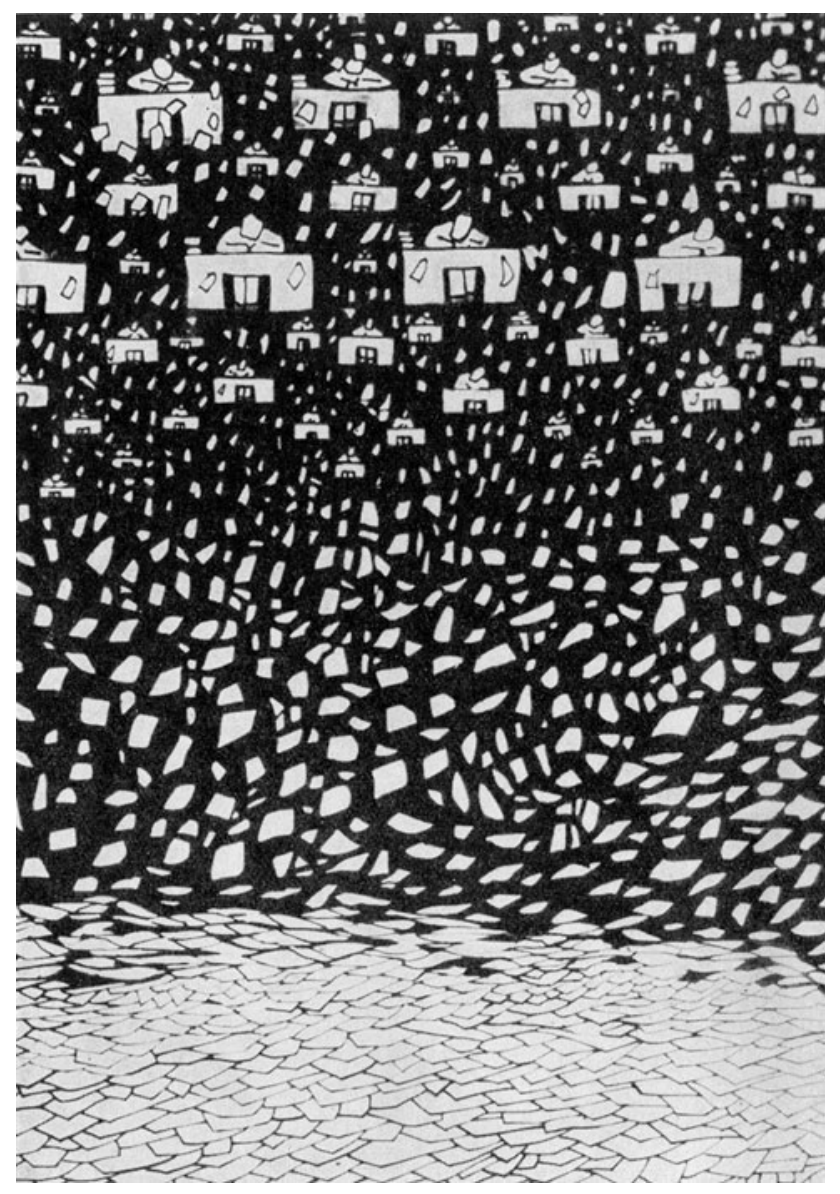

Eugen Wegmann: Die wissenschaftliche Literatur (Geologische Rundschau, 1939, v. 30, p. 390). C. Eugen Wegmann (1896-1982) was a prominent geologist in the middle of the 20th century. He was one of the two or three doctoral students of Emile Argand in Neuchâtel, but left Switzerland in 1924, when the glorious days of Alpine geology had passed, to apply Argand's concepts to the deepseated foundations of orogenies in Scandinavia and Greenland. From this effort, a number of truly original papers on the structure of highgrade metamorphic terranes resulted, e.g. his famous study on migmatites (1935). These papers were clearly outside the mainstream of petrology. In 1940, Wegmann succeeded Argand as the chair in Neuchâtel and held this seat until 1964. His critical attitude and his sense of humour, which are both apparent in his drawings, must have been essential assets for him when, as a co-editor of the Rundschau from 1948 to 1958, he engaged himself to the re-establishment of the journal after World War II. In 1959, Wegmann received the Steinmann Medal of the Geologische Vereinigung; his legacy is now in the Geologen-Archiv in Freiburg i.Br.

On April 26th, 1910, the first issue of the Geologische Rundschau appeared in print including a wide range of topics such as the following: Alpen und Apennin auf Sardinien und
Korsika by A. Tornquist, and Gebirgsbildung und Massengesteine in der Kordillere Südamerikas by G. Steinmann. Since its first issue, the Geologische Rundschau has published a number of classical landmark papers. Some of these have been translated and re-published as a collection in the "Golden Volume" of the "Rundschau", as the journal was informally called by most geoscientists in the last century and by many still today. On April 1st, 1999, the Rundschau changed its name to the International Journal of Earth Sciences. By doing this, the journal has gained more international recognition, although the Rundschau has always had an international focus. Competition among scientific journals has grown in recent decades, as expressed by the impact factor. In 1995, this factor for the Rundschau was 0.68 , in 2001 it was 1.48 , and 100 years after its first issue, the journal has achieved the remarkable score of 2.44. This underlines the growing popularity of the journal on the one hand, and on the other hand, it honours the founders of our association, who had an outstanding vision by launching the Geologische Rundschau as their periodical.

However, the rapid evolution of our science and the accompanying specialization should not obscure the large picture. Geoscientists study the complex "System Earth" in order to better understand its individual components as well as the system as a whole (see the strategy paper of the DFG Geocommission: Dynamische Erde-Zukunftsaufgaben der Geowissenschaften). Eugen Wegmann brought attention to this issue as early as 1939 in his cartoon, "The Scientific Literature", one of two drawings relating to geological study. Today, we should interpret his cartoon as a lesson not to become isolated and too specialized, and not to lose sight of the real goals of our science.

We hope that you have opportunities for many fruitful discussions and gain a lot of new interesting information during our celebration of the 100th anniversary of the Geologische Vereinigung on October 10th, 2010 in Frankfurt, and the following annual meeting to be held together with the Deutsche Gesellschaft für Geowissenschaften in Darmstadt (11th-13th October, 2010).

August 2010 